\title{
The foot and ankle characteristics in children with idiopathic toe walking gait
}

\author{
Cylie Williams ${ }^{1,2^{*}}$, Paul Tinley ${ }^{3}$, Michael Curtin ${ }^{4}$, Sharon Nielsen ${ }^{5}$ \\ From Australasian Podiatry Council Conference 2013 \\ Sydney, Australia. 2-5 June 2013
}

\section{Background}

Idiopathic toe walking (ITW) has been associated with ankle equinus, and while equinus has been linked with foot deformity in adults, there has been limited investigation on its impact on structural foot change in children. This study used the weight bearing lunge (WBL) test and Foot Posture Index-6 (FPI-6) to evaluate the foot and ankle measures of children with an ITW gait.

\section{Methods}

Sixty children between the ages of four and eight years were grouped into an ITW $(\mathrm{N}=30)$ and a non-toe walking (NTW) $(\mathrm{N}=30)$ cohort. The ankle range of movement and FPI- 6 was calculated during appropriate weight-bearing test and stance.

\section{Results}

There was a highly significant difference in the WBL test measures between the ITW cohort and the NTW cohort. The FPI-6 comparison was not significant. The WBL test was also not predictive of an abnormal FPI-6 in the ITW cohort.

\section{Conclusion}

These results demonstrate that ITW gait style impacts only on the available dorsiflexion at the ankle. The WBL measure may be utilised within the clinical setting to guide and monitor treatment interventions.

\section{Author details}

'Allied Health Research Unit, Southern Health, Cheltenham, VIC, 3192, Australia. ${ }^{2}$ Department of Physiotherapy, Monash University, Frankston, VIC, 3199, Australia. ${ }^{3}$ School of Podiatry, Charles Sturt University, Albury, NSW, 2460, Australia. ${ }^{4}$ School of Occupational Therapy, Charles Sturt University,

\footnotetext{
*Correspondence: cylie.williams@southernhealth.org.au

'Allied Health Research Unit, Southern Health, Cheltenham, VIC, 3192, Australia

Full list of author information is available at the end of the article
}

Albury, NSW, 2460, Australia. ${ }^{5}$ Quantitative Consulting Unit, Charles Sturt University, Wagga Wagga, NSW, 2678, Australia.

Published: 31 May 2013

doi:10.1186/1757-1146-6-S1-039

Cite this article as: Williams et al:: The foot and ankle characteristics in children with idiopathic toe walking gait. Journal of Foot and Ankle Research 2013 6(Suppl 1):039.
Submit your next manuscript to BioMed Central and take full advantage of:

- Convenient online submission

- Thorough peer review

- No space constraints or color figure charges

- Immediate publication on acceptance

- Inclusion in PubMed, CAS, Scopus and Google Scholar

- Research which is freely available for redistribution
() Biomed Central

\section{Biomed Central}

